\title{
Preparing a comprehensive geodatabase for Iraq geodetic networks systems
}

\author{
Oday Jasim ${ }^{1, *}$ Khalid Hassoon ${ }^{2}$, and Mazin Hussein ${ }^{1}$ \\ ${ }^{1}$ Building and Construction Engineering Department, University of Technology, Baghdad, Iraq \\ ${ }^{2}$ Ministry of Science and Technology, Baghdad, Iraq
}

\begin{abstract}
This paper concerns the subject geodetic networks data in Iraq and the need to put them in specialized spatial databases that can be updated and developed, which makes it much easier for those concerned such as scientific researchers ad surveying engineers to access these data and use them in scientific applications and Engineering projects. The practical aspect of this study was divided into three stages, the first stage was limited to the collection of official data related to the main projects of geodetic networks in Iraq, beginning with the first English network 1934, the second English network 1967, the Polish network 1979, the gravitational networks 1963-1984, and ending with the CORS-HARN networks that have been based in their observations and calculations upon the GPS. The second stage consists of sorting the data obtained from the first stage, and then entering the selected data into spatial databases. The third stage includes the reconnaissance, ground survey and verification of data obtained from the second stage. Furthermore, it also showed that all the English networks, the first 1934 and the second 1967, as well as the points of gravity were almost completely extinct and it became difficult to identify any traces of any of its points within this region.
\end{abstract}

\section{Introduction}

It is well known that the geodetic networks have fundamental importance in surveying. Generally there are four types of these networks: horizontal, vertical combined 3D System (horizontal and vertical) and gravity, each type has specific trends and applications, in Iraq. From historical point of view, the development of these networks can be categorized as shown in figure 1

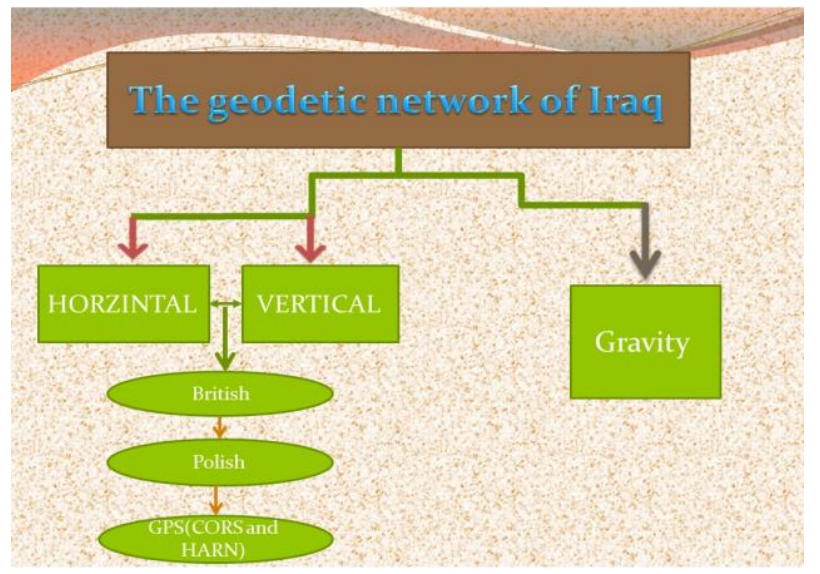

Fig.1. Geodetic network in Iraq

\section{Review historical development for Iraqi geodetic networks}

\subsection{First British network of Iraq1934}

The first geodetic network of Iraq was created by the English oil companies in 1934 and called the name (Nahrwan Datum 1934) on this network as a label Nahrawan is the ratio to the city in southeastern Baghdad, where it was relying on the reference in this region point to be a reference to the system of coordinates the adoption of this network in drawing all first property maps of Iraq and used up to the present time which what is known maps Alcadstro in addition to other different maps have been benefit from it in the planning of infrastructure projects. The flatfish surfaces (CLARKE 1880) have been used Theodolite instrument, settlement and painting and planar chain in the creation of this network has been relying on the sea level (M.S.L) [1]The Primary Triangulation of Iraq.-The primary triangulation of Iraq is only of secondary precision and was executed between 1930-1934. It is divided into two series: the North Series arid the South Series. Both the series start with the measured base at Nahrwan (E. of Baghdad). The North Series closes on a measured base at Kirkuk and the South Series at Batha. The measured

* Corresponding author 40004@uotechnology.edu.iq 
values of the bases have been accepted and discrepancies between the triangulated and measured values have been adjusted. The details are given below:

Table 1. The measured values of the bases in British first Network of Iraq1934

\begin{tabular}{|c|c|c|c|c|}
\hline no & $\begin{array}{c}\text { Name of } \\
\text { base }\end{array}$ & $\begin{array}{c}\text { Data of } \\
\text { measurement }\end{array}$ & $\begin{array}{c}\text { Length } \\
(\mathbf{m})\end{array}$ & $\begin{array}{c}\text { Probable } \\
\text { Error } \\
(\mathbf{m m})\end{array}$ \\
\hline 1 & Nahrwan & 1930 & 4441.01448 & \pm 3.00 \\
\hline 2 & Kirkuk & 1930 & 2000.30950 & \pm 3.34 \\
\hline 3 & Batha & 1930 & 2012.17679 & \pm 2.40 \\
\hline
\end{tabular}

The initial latitude and longitude are the astronomical values of Nahrwin $\mathrm{S}$. End Base:

Latitude 33" 19' 10" .87 \pm 0 " .20 (for N \& S. stars)

Longitude 44" 43' 25" .64 \pm 0 " .69 (from wireless time signals)

\subsection{Second British network of Iraq 1967}

The establishment of a new system in 1967, flat depends surface flatfish (CLARKE 1880) and projected UTM PROJECTION) The reference point in Nahrawan region called locally "binary system .whereas elevation level depends sea level at FAO as basis for elevation system currently called GTS .This system used until 1980 .but the information about this system was little and it is called nahrwan datum 1976 whereas projection that was used (PROJECTION) has Been projected to use the UTM the following specifications [1]

1 -Central Meridian $=46^{\circ} 30^{\prime} 00^{\prime \prime} \mathrm{E}$

2-Origion Latitude $=29^{\circ} 01^{\prime} 34.5560^{\prime \prime} \mathrm{N}$

3-Scale Factor $=0.9994$

4-False Easting $=800000 \mathrm{~m}$

5 -False northing $=0.00 \mathrm{~m}$

\subsection{Polish geodetic control networks of Iraq 1974-1979}

\subsubsection{Horizontal networks}

It is the period from 1974-1979, where the one of the competent international companies in this field (Pole Service Company) establishment of a network adjust the horizontal and vertical first-order at the country level extra to do a lot of work surveying Other, These can be one of the best geodetic networks in the region network considered at that time where it was using the latest instruments and techniques in the development of this network has been chosen flounder CLARCK1880andprojectedUTM.The following specifications

1-The horizontal network consisting of 2778 stations distributed in all over the country

2-50 Laplace azimuth/average mean square error $\pm 0.42^{\prime \prime}$

3-8606 distances measured by means of AGA8 /mean square error of distance $5 \mathrm{~mm}+1.10^{-6} \mathrm{D}$

4-316 distances measured by means of tellurometers /mean square error of distance $15 \mathrm{~mm}+3.10^{-6} \mathrm{D}$

5-1267 angle /average mean square error $\pm 4^{\wedge} \mathrm{cc}$ the mean square error of the distance after adjustment is equal to $22 \mathrm{~mm}$

6- The distances are ranging from 8 to 35 kilometers, while mean distance is about 15 kilometers.

7- The primary control is countrywide-trilateration net, in which all the distances between consecutive points and also some selected angles are measured.

8- 24 Base line which connects Laplace points[2]

\subsubsection{Vertical networks}

It has been relying on the sea MSL level rate where he was erected two station-Gauge Tide for about two weeks "in the Fow region of the Arabian Gulf and recording the highest elevations readings and took her average per day and record readings lower elevations and took her average per day and then taking those rates and took rate of two per day and then taking the rates of these days and taking the average of the sum of these days to station one and then two rate This is attributed to a zero meters, which depends on the double minute settlement process for the distribution of the vertical grid points, the whole area of the country51 leveling lines from 21 closed perimeters the average length of a line is 180 kilometers, the average length of a perimeter600 kilometers. The bench-marks on precise leveling lines are situated at a distance of about 5 kilometers one from another in rural and desert areas and 2 kilometers in developed and urban areas, which amounts to up to 1984 station bench marks. The trigonometrically leveling net adjustment comprises 5357 vertical angular observation single or double and was based on leveled point the mean square error of adjusted height does not exceed $0.5 \mathrm{~m}$, while the average value is $0.3 \mathrm{~m}$. [3]

\subsection{Gravity basic station network of Iraq1963- 1984}

Gravity basic station are found mental for regional and detailed gravity surveys previously foreign oil companies conducted regional gravity survey using basic station apparently connected to the Syrian net unfortunately on information could be obtained concerning location values and accuracies of the basic station. First document information available were these of six international basic stations established in Iraq by woolard in 1963 and connected with world gravity net of wiscons in university. Arose to create basic station to carryout regional gravity survey in an covered area of Iraq. So in the period between 1969-1977 some 180 basic station were established and connected with woolard. On the initiative of geophysical determent of Som a five year plane to established gravity basic station 
net. Covering the whole territory of Iraq was projecting .462 basic stations distributed all over country, mostly on triangulation point and benchmarks of polservis were established, measured and al aborted during the years 1979-1984. These basic stations were connected to the previously established ones making a total of 648 gravity basic stations covering the territory of Iraq [4] as in figure 2

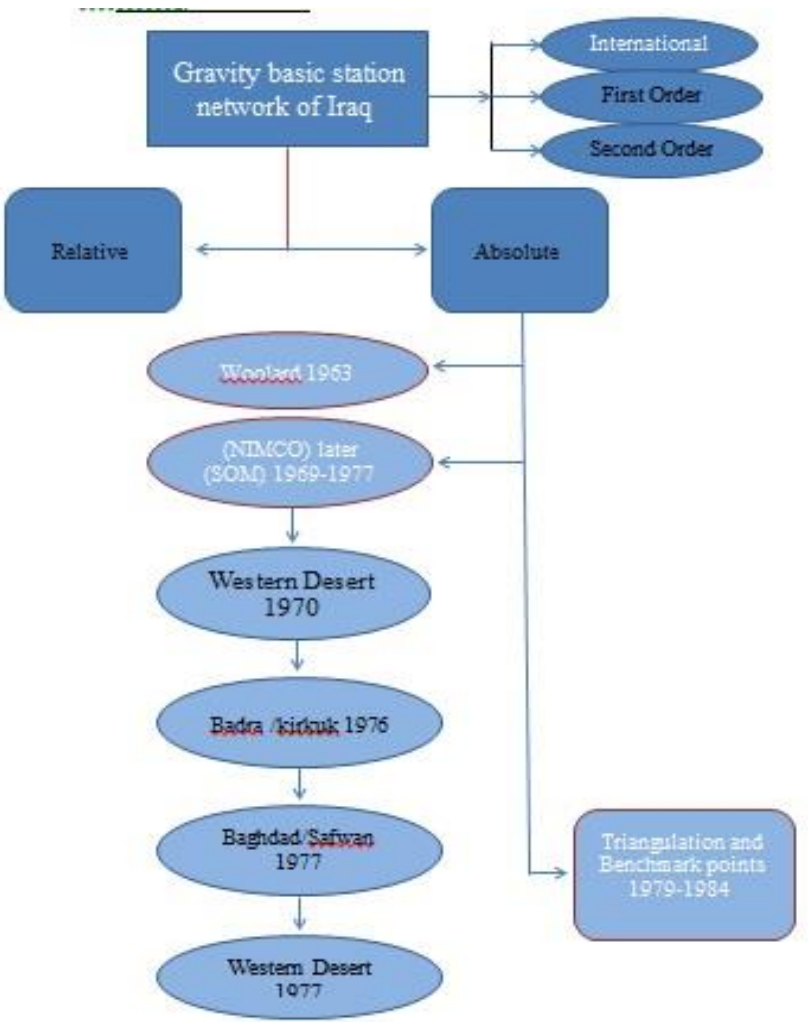

Fig.2. Historical development of gravity basic stations network in Iraq .

\subsection{Iraqi geospatial reference system 2004 - 2016}

During the period from 2004 to 2005, the American institution for the National Geodetic Survey, which is considered one of the most prestigious Institutions in the competent Geodesy world, prepared the plan for the project geodesy network development in Iraq, The project has been started and the completion of part of it, but without the participation of the Iraqi side and the project was renamed IRAQI GEOSPATIAL REFRENCE SYSTEM (IGRS).

the work done by this institution has been Distinguished by ber formic two major tasks

1 -The first is the monument 6 of reference CORS stations

2-The second is erected 64 adjusted Stations of the three-dimensional first-class or as-called points of HARN in four provinces.(southern )

At the beginning of 2007 the Authority General of surveying started to think about completing the stoppage work and the addition of some other important things and already has been moving and start racing to activate the project, but at a slow pace due to lack of expertise and cadres . In fact such that acts have always been and still carried out by companies and institutions world with experience in this field it has been identified that, the goals of this new project follows as in figure 3

- Adoption of the Universal ITRF system as the basis for a new system of coordinates, according to the recommendation of the US geodesy Authority NGS

- Adoption of flatfish WGS84 Ellipsoid

- The adoption of the Universal projected UTM

- Installed new network is made up of seven reference CORS and world-class associated with the World Wide Web will be the basis for the new system of coordinates of stations and provide a free service for users to fully and be this network is an alternative to the old network because of a stoppage and not to the possibility of reentry to work in addition to the new network will be controlled by the Directorate General of surveying fully

- Continue to install the ground control stations, threedimensional HARN (High Accuracy Reference Network) in the provinces and in the same specifications stations which installed previously with some modifications in the site selection process and the establishment of stations. [1]

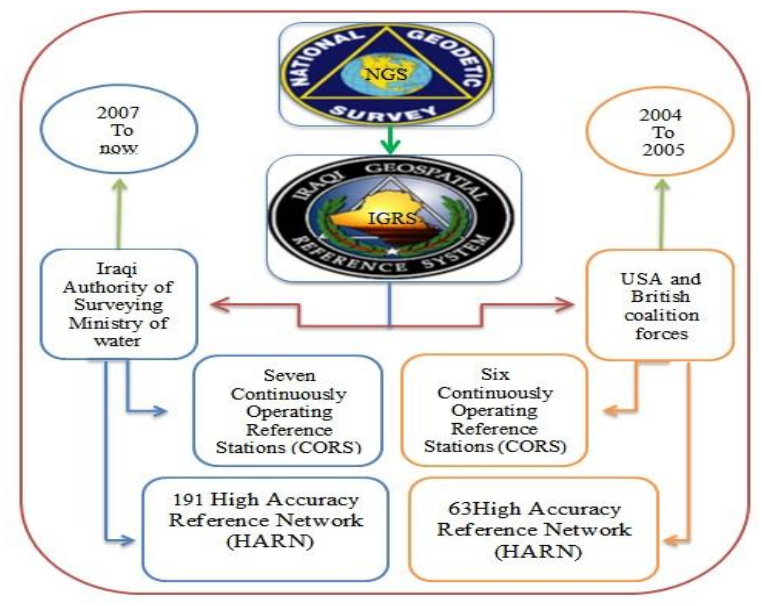

Fig. 3. Iraqi geospatial reference system

\subsubsection{Continuously Operating Reference Stations of USA and British (CORS)}

The monument 6 of reference CORS stations and connect them with the institution of the NGS which provide data and processing of data for these stations free of charge to users where these stations regarded as the basis of Iraq's new coordinate system, which depends on the center of the globe as a point of reference have been chosen coordinates of ITRF2000 system as a basis for work and according to international standards accredited [1].The distribution points in the military headquarters of the multinational forces, of the table as follows (table-2) 
Table-2 distribution the USA CORS stations in Iraq

\begin{tabular}{|c|c|c|c|}
\hline $\begin{array}{c}\text { Code } \\
\text { station }\end{array}$ & Location & $\begin{array}{c}\text { Code } \\
\text { station }\end{array}$ & Location \\
\hline IZ BD & Baghdad & IZTL & Thi Qar \\
\hline IZ BA & Basrah & IZ AD & Anbar \\
\hline IZ BL & Salahuddin & IZQW & Nainawa \\
\hline
\end{tabular}

\subsubsection{High accuracy reference network of USA and British (HARN)}

Erected 63 Stations Ground adjust the threedimensional first-class or as-called points of HARN in four provinces, as shown as follows .It utilized to international standards in the establishment and monitoring points and in accordance with the six reference stations and were prepared. Data bases of these points which have been distributed in the province of Basrah, Muthanna,. Maysan and Thi Qar.. [1]



Fig.4. Block diagram The Materials and Methods

\subsubsection{Continuously Operating Reference Stations of Iraqi general authority for surveying (CORS)}

Seven stations have been installed during the period from 2008 to the end of 2009 in each of the governorates
(Erbil, Salahuddin, Baghdad, Najaf, Kut, Basra and Zakho).

2.5.4 High accuracy reference network of Iraqi general authority for surveying (HARN)

The High Accuracy Reference System (HARN )is three-dimensional control points be monitored by system of GPS particular way and depending on the stations of the CORS and be given a central geodetic coordinates and quadratic depending on the global system ITRF surface flatfish WGS84 and projected UTM in addition to providing a national level, depending on the Polish network of vertical and most of the points is done through method double accurate leveling thus can rely on these points in the topographic surveys using GPS RTK Technology System .where During 2005 the institution of NGS installed 64 distributed stations in the provinces (Basra, Maysan, Dhi Qar, Muthanna) but without giving the levels depends on the sea level and is currently completing the work in the installed stations in other provinces are currently working shut down due to lack of financial allocations were So far, 191 Have been installed distributed station in the country's governorates. [1]

\section{Problem statements}

In the past eight decades, different geodetic projects have been planned and implemented within Iraq country, the hypothesis of this thesis based on representing the main problem in these projects was not in their accuracy or in their technical approaches rather than in the official documentation of them. However, two indicators for weak documentation process have been noticed, as follows:

A- Throughout searching in the Internet about the specialized publications of geodetic control networks in Iraq, the acquired documents (technical reports, maps, sketches, theses, papers, datasheets) are too few and do not reflect the reality of these huge geodetic projects that had been implemented in Iraq.

B- If anyone could visit the scientific libraries of the specialized directorates in geodetic surveying, he will not find the standardized archiving for the documents related with geodetic control networks in Iraq.

\section{Materials and methods}

To study in depth the thesis problem, different materials and methods in figure 4 are to be prepared and arranged as follows:

A- The authorized documents including maps, sketches, technical reports, datasheets in both hardcopy and digital formats

B- Utilizing ArcGIS software package to design and implement the required spatial data base for geodetic control networks ( with their different types, i.e. 
traditional horizontal, traditional vertical, gravity and CORS-HARN ),

C- Other software packages have been used in minor operations that are required in preparing the geodetic geodatabases, as follows:

1- ERDAS Imagine: has been used in coordinates transformations of geodetic control points within different networks.

2- Microsoft Excel: was required in initial editing of the tabular data that are related with the geodetic geodatabases.

D- Geodetic GPS device (Topcon GR3 model) has been used as ground truth by field re-surveying for selected geodetic control points within two Governorates ( Babil and Kerbaka).

\section{Result}

According to the availability of the Iraqi geodetic data, a comprehensive geodatabse has been prepared (using the ArcGIS software package), this geodatabse consists of different datasets as shown in figures 5-16 and tables 3-6

\subsection{Polish geodetic control networks of Iraq 1974-1979}

\subsubsection{Polish geodetic horizontal networks}

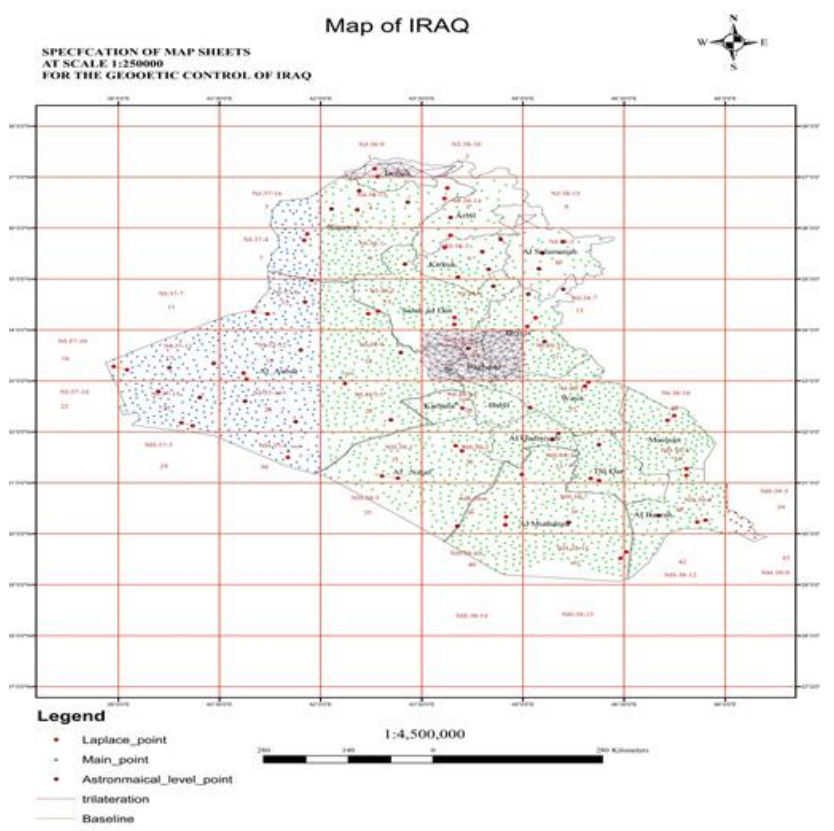

Fig.5. Map of polish geodetic horizontal networks



Fig.6. Geodatabase for polish geodetic horizontal networks

Table.3 Geodatabace for polish geodetic horizontal networks

\begin{tabular}{|c|c|c|c|c|c|}
\hline StNr & E_utm & N_utm & Height & $\begin{array}{c}\text { Dist_o } \\
\text { bsv }\end{array}$ & $\begin{array}{c}\text { Angle_ } \\
\text { obs }\end{array}$ \\
\hline 1001 & $\begin{array}{c}339329 . \\
9\end{array}$ & $\begin{array}{c}412832 \\
0\end{array}$ & 2161.6 & AGA_8 & $\begin{array}{c}\text { Wild_T } \\
3\end{array}$ \\
\hline 1002 & $\begin{array}{c}323013 . \\
5\end{array}$ & $\begin{array}{c}412405 \\
1\end{array}$ & 1766.2 & AGA_8 & $\begin{array}{c}\text { Wild_T } \\
3\end{array}$ \\
\hline 1003 & $\begin{array}{c}310354 \\
8\end{array}$ & $\begin{array}{c}412619 \\
1\end{array}$ & 1982.8 & AGA_8 & $\begin{array}{c}\text { Wild_T } \\
3\end{array}$ \\
\hline 1004 & $\begin{array}{c}293071 . \\
5\end{array}$ & $\begin{array}{c}412233 \\
5\end{array}$ & 870.6 & AGA_8 & $\begin{array}{c}\text { Wild_T } \\
3\end{array}$ \\
\hline 1005 & $\begin{array}{c}355135 \\
2\end{array}$ & $\begin{array}{c}411829 \\
9\end{array}$ & 1548.6 & AGA_8 & $\begin{array}{c}\text { Wild_T } \\
3\end{array}$ \\
\hline 1006 & $\begin{array}{c}304670 . \\
1\end{array}$ & $\begin{array}{c}411552 \\
5\end{array}$ & 753.1 & AGA_8 & $\begin{array}{c}\text { Wild_T } \\
3\end{array}$ \\
\hline 1007 & $\begin{array}{c}319781 \\
4\end{array}$ & $\begin{array}{c}411432 \\
5\end{array}$ & 969.4 & AGA_8 & $\begin{array}{c}\text { Wild_T } \\
3\end{array}$ \\
\hline 1008 & $\begin{array}{c}336084 \\
7\end{array}$ & $\begin{array}{c}411306 \\
0\end{array}$ & 1412.2 & AGA_8 & $\begin{array}{c}\text { Wild_T } \\
3\end{array}$ \\
\hline 1009 & $\begin{array}{c}345411 . \\
7\end{array}$ & $\begin{array}{c}411142 \\
4\end{array}$ & 2086.7 & AGA_8 & $\begin{array}{c}\text { Wild_T } \\
3\end{array}$ \\
\hline 1011 & $\begin{array}{c}275681 . \\
8\end{array}$ & $\begin{array}{c}410753 \\
1\end{array}$ & 1071.3 & AGA_8 & $\begin{array}{c}\text { Wild_T } \\
3\end{array}$ \\
\hline 1012 & $\begin{array}{c}292036 . \\
2\end{array}$ & $\begin{array}{c}410402 \\
3\end{array}$ & 1117.5 & AGA_8 & $\begin{array}{c}\text { Wild_T } \\
3\end{array}$ \\
\hline 1013 & $\begin{array}{c}321854 \\
3\end{array}$ & $\begin{array}{c}410232 \\
4\end{array}$ & 966.9 & AGA_8 & $\begin{array}{c}\text { Wild_T } \\
3\end{array}$ \\
\hline 1014 & $\begin{array}{c}308403 . \\
1\end{array}$ & $\begin{array}{c}409790 \\
1\end{array}$ & 1385.8 & AGA_8 & $\begin{array}{c}\text { Wild_T } \\
3\end{array}$ \\
\hline 1015 & $\begin{array}{c}341059 \\
4\end{array}$ & $\begin{array}{c}409659 \\
4\end{array}$ & 1508.4 & AGA_8 & $\begin{array}{c}\text { Wild_T } \\
3\end{array}$ \\
\hline
\end{tabular}


Table.4 Geodatabase for lines bench mark in polish geodetic

\section{5-1-2 Polish geodetic vertical networks}

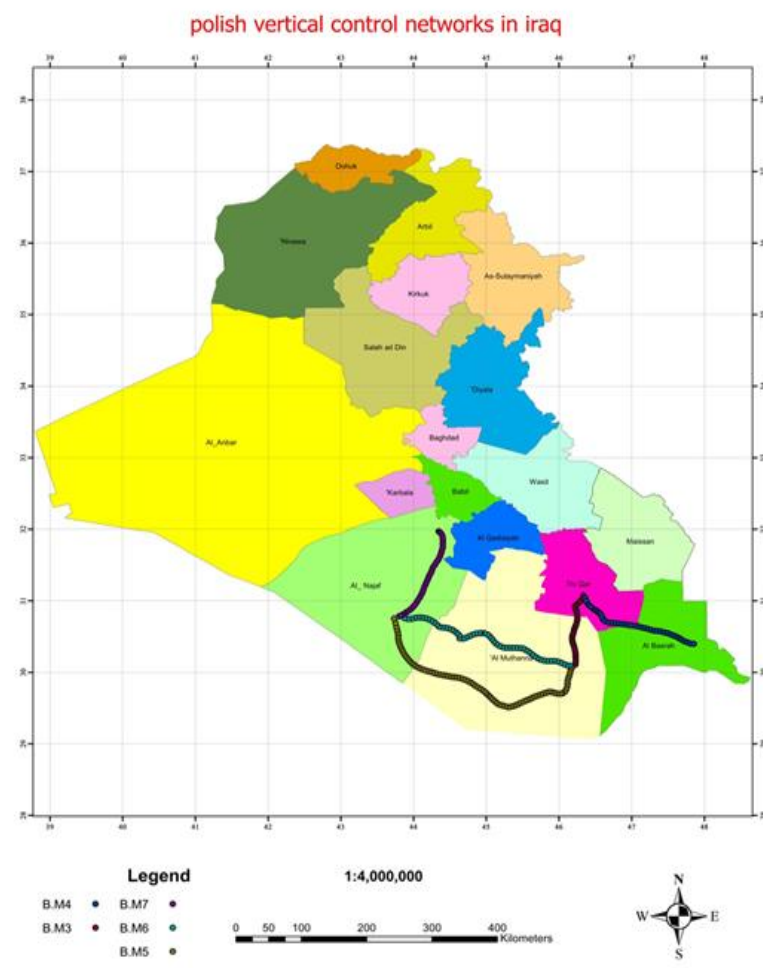

Fig.7. Map of polish geodetic vertical networks

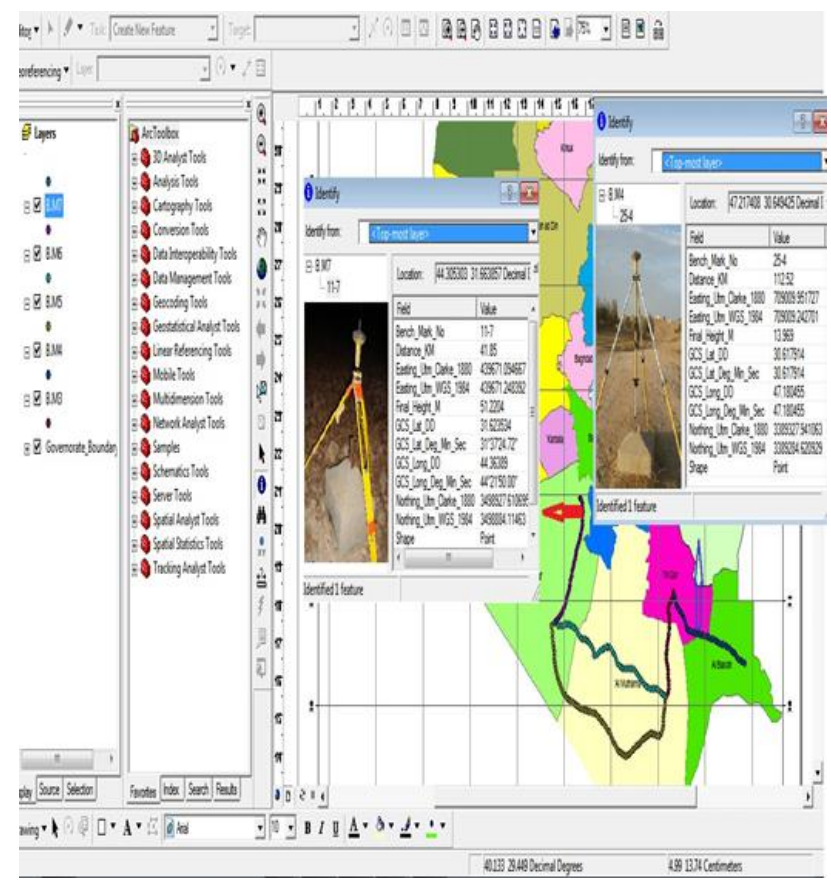

Fig.8 Geodatabase for polish geodetic vertical networks vertical networks

\begin{tabular}{|c|c|c|c|c|}
\hline B.M_no & Dis_KM & Final_H_M & $\begin{array}{c}\text { GCS_Long } \\
\text { Deg_Min_GCS_Lat_ } \\
\text { Sec }\end{array}$ & $\begin{array}{c}\text { Deg_Min_S } \\
\text { CC }\end{array}$ \\
\hline $1-4$ & 4.99 & 3.7432 & 46.359541 & 31.034796 \\
\hline $2-4$ & 10 & 4.7711 & 46.376435 & 30.991966 \\
\hline $3-4$ & 15.56 & 4.6174 & 46.401419 & 30.947708 \\
\hline $4-4$ & 18.45 & 3.8859 & 46.421645 & 30.930338 \\
\hline $5-4$ & 21.92 & 3.9189 & 46.446867 & 30.909874 \\
\hline $6-4$ & 27.22 & 4.8185 & 46.483749 & 30.878941 \\
\hline $7-4$ & 29.91 & 4.5325 & 46.504926 & 30.867044 \\
\hline $8-4$ & 32.99 & 2.6631 & 46.528483 & 30.852291 \\
\hline $9-4$ & 36.03 & 3.5782 & 46.549422 & 30.833493 \\
\hline $10-4$ & 39.07 & 2.8296 & 46.571789 & 30.816599 \\
\hline $11-4$ & 43.93 & 4.2632 & 46.59249 & 30.774959 \\
\hline $12-4$ & 48.95 & 8.5594 & 46.613191 & 30.731653 \\
\hline $13-4$ & 53.03 & 18.0333 & 46.645076 & 30.711665 \\
\hline $14-4$ & 57.81 & 18.5569 & 46.685527 & 30.695247 \\
\hline
\end{tabular}

\subsection{Gravity basic station network of Iraq1963- 1984}

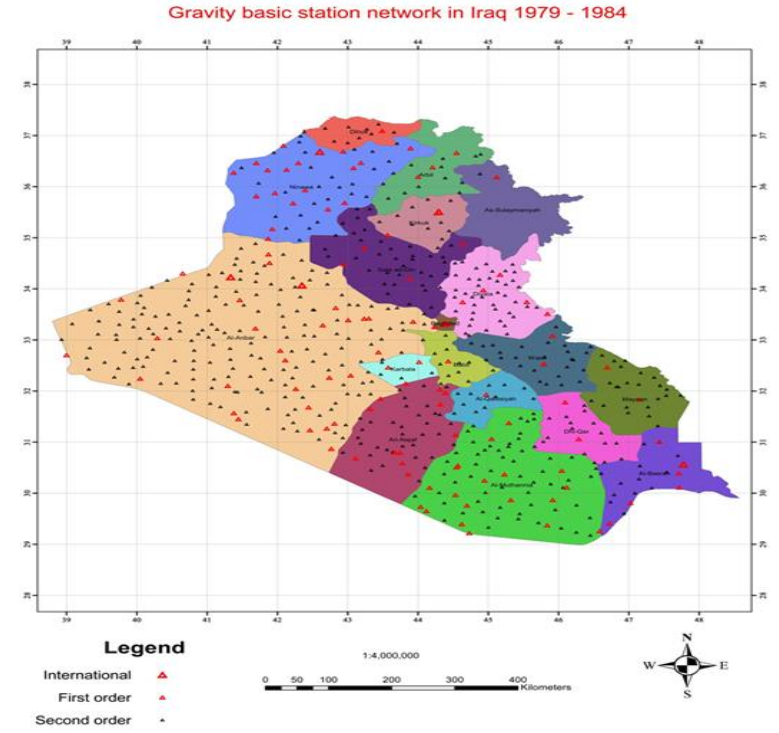

Fig.9. Map for gravity basic stations network 
Table.5 Geodatabase for gravity basic stations network.

\begin{tabular}{|c|c|c|c|c|c|c|}
\hline $\begin{array}{l}\text { Code of } \\
\text { Basic } \\
\text { Station }\end{array}$ & $\begin{array}{c}\text { Orde } \\
\mathbf{r}\end{array}$ & $\begin{array}{c}\text { Y } \\
\text { UTM }\end{array}$ & $\begin{array}{c}\text { X } \\
\text { UTM }\end{array}$ & $\begin{array}{l}\text { Elev. } \\
\text { UTM }\end{array}$ & \begin{tabular}{|c|} 
Absolut \\
$\mathrm{e}$ \\
gravity \\
value \\
(mgal)
\end{tabular} & $\mid \begin{array}{c}\text { Old of } \\
\text { Basic } \\
\text { Station }\end{array}$ \\
\hline $\mathrm{NCDa} 2$ & 2nd & $\begin{array}{c}4106113.00 \\
0\end{array}$ & $\mid \begin{array}{c}267007.00 \\
0\end{array}$ & & $\begin{array}{c}979 \\
794.27\end{array}$ & \begin{tabular}{|l|}
\multicolumn{1}{|c}{ Fish } \\
Khabou \\
$\mathrm{r}$
\end{tabular} \\
\hline $\begin{array}{c}\text { NCDab } \\
1\end{array}$ & 2 nd & $\begin{array}{c}4113279.00 \\
0\end{array}$ & \begin{tabular}{|c|}
293873.00 \\
0
\end{tabular} & & \begin{tabular}{|c|}
979 \\
794.82 \\
\end{tabular} & Zach \\
\hline $\mathrm{NCDb} 2$ & 2nd & $\begin{array}{c}4120868.00 \\
0\end{array}$ & \begin{tabular}{|c|}
361428.00 \\
0
\end{tabular} & & \begin{tabular}{|c|}
979 \\
572.14 \\
\end{tabular} & \begin{tabular}{|c|} 
Kani \\
Masi
\end{tabular} \\
\hline $\mathrm{NCDb} 1$ & 2nd & $\begin{array}{c}4115383.00 \\
0\end{array}$ & $\begin{array}{c}323417.00 \\
0\end{array}$ & & \begin{tabular}{|c|}
979 \\
660.83 \\
\end{tabular} & $\begin{array}{ll} & \text { Batuf } \\
\end{array}$ \\
\hline NDa3 & 2nd & $\begin{array}{c}4110307.00 \\
0\end{array}$ & $\begin{array}{c}346518.00 \\
0\end{array}$ & & \begin{tabular}{|c|}
979 \\
590.70 \\
\end{tabular} & rni \\
\hline 1 & $1 \mathrm{st}$ & $\begin{array}{c}4105909.00 \\
0\end{array}$ & $\begin{array}{c}365726.00 \\
0\end{array}$ & & \begin{tabular}{|c|}
979 \\
579.16 \\
\end{tabular} & \begin{tabular}{|c|} 
Ama \\
diya
\end{tabular} \\
\hline NDa4 & 2nd & $\begin{array}{c}4100033.00 \\
0\end{array}$ & $\begin{array}{c}352139.00 \\
0\end{array}$ & & \begin{tabular}{|c|}
979 \\
624.78 \\
\end{tabular} & nk \\
\hline NDb1 & 2nd & \begin{tabular}{|c|}
4103002.00 \\
0 \\
\end{tabular} & $\begin{array}{c}380723.00 \\
0 \\
\end{array}$ & & \begin{tabular}{|c|}
979 \\
697.75 \\
\end{tabular} & \begin{tabular}{|c|} 
Balen \\
$\mathrm{da}$
\end{tabular} \\
\hline NB1 & 2nd & $\begin{array}{c}4062054.00 \\
0\end{array}$ & $\begin{array}{c}763469.00 \\
0\end{array}$ & $\begin{array}{c}377.70 \\
0\end{array}$ & $\begin{array}{c}979 \\
775.99 \\
\end{array}$ & $\begin{array}{c}\text { TP } \\
03001\end{array}$ \\
\hline NCDa1 & 2nd & $\begin{array}{c}4097362.00 \\
0\end{array}$ & $\begin{array}{c}262357.00 \\
0\end{array}$ & $\begin{array}{c}484.30 \\
0\end{array}$ & \begin{tabular}{|c|}
979 \\
775.73
\end{tabular} & $\begin{array}{c}\text { TP } \\
04001\end{array}$ \\
\hline $\mathrm{NC} 1$ & 2nd & $\begin{array}{c}4084396.00 \\
0\end{array}$ & $\begin{array}{c}260461.00 \\
0\end{array}$ & & \begin{tabular}{|c|}
979 \\
805.23
\end{tabular} & $\begin{array}{r}\text { Wadi } \\
\text { Swedi }\end{array}$ \\
\hline 2 & $1 \mathrm{st}$ & $\begin{array}{c}4076827.00 \\
0\end{array}$ & $\begin{array}{c}239781.00 \\
0\end{array}$ & & $\begin{array}{c}979 \\
780.38 \\
\end{array}$ & a \\
\hline NBC & 2nd & $\begin{array}{c}4062092.00 \\
0\end{array}$ & $\begin{array}{c}267189.00 \\
0\end{array}$ & & \begin{tabular}{|c|}
979 \\
792.90 \\
\end{tabular} & $\begin{array}{c}\text { Tel } \\
\text { Awainat }\end{array}$ \\
\hline
\end{tabular}



Fig.10. Geodatabase for gravity basic stations network

\subsection{Continuously operating reference stations of USA and British (CORS)}

CORS Station in IRAQ 2005 - NGS

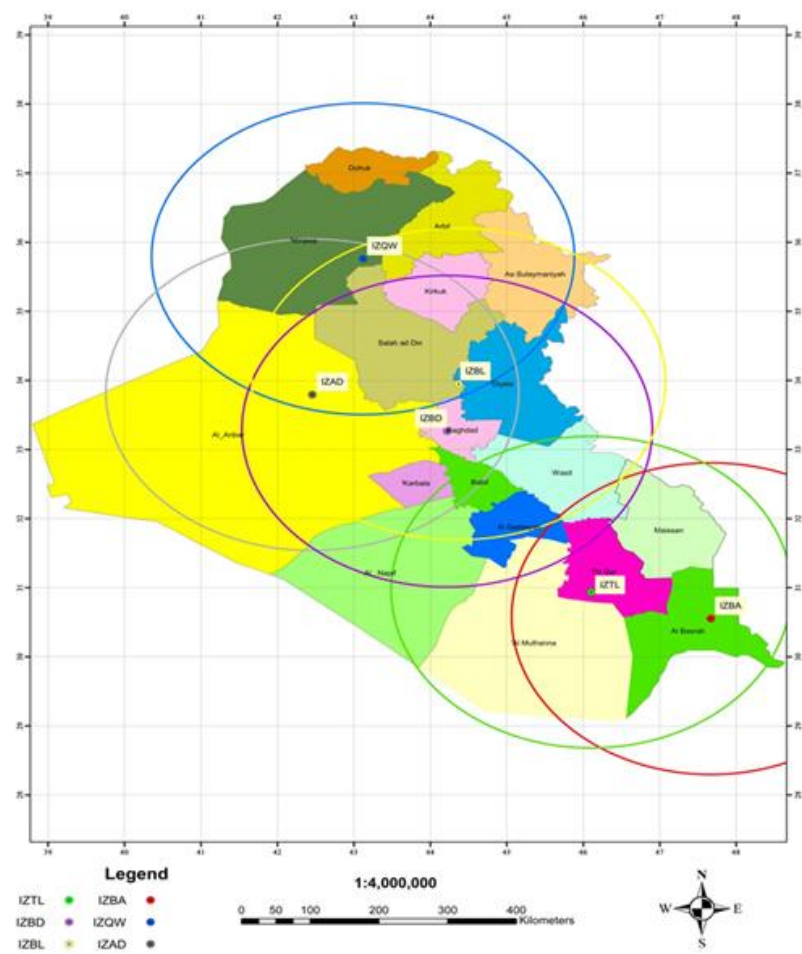

Fig.11. Map the (CORS) network 2005 in Iraq - NGS

\subsection{High accuracy reference network of USA and British (HARN)}

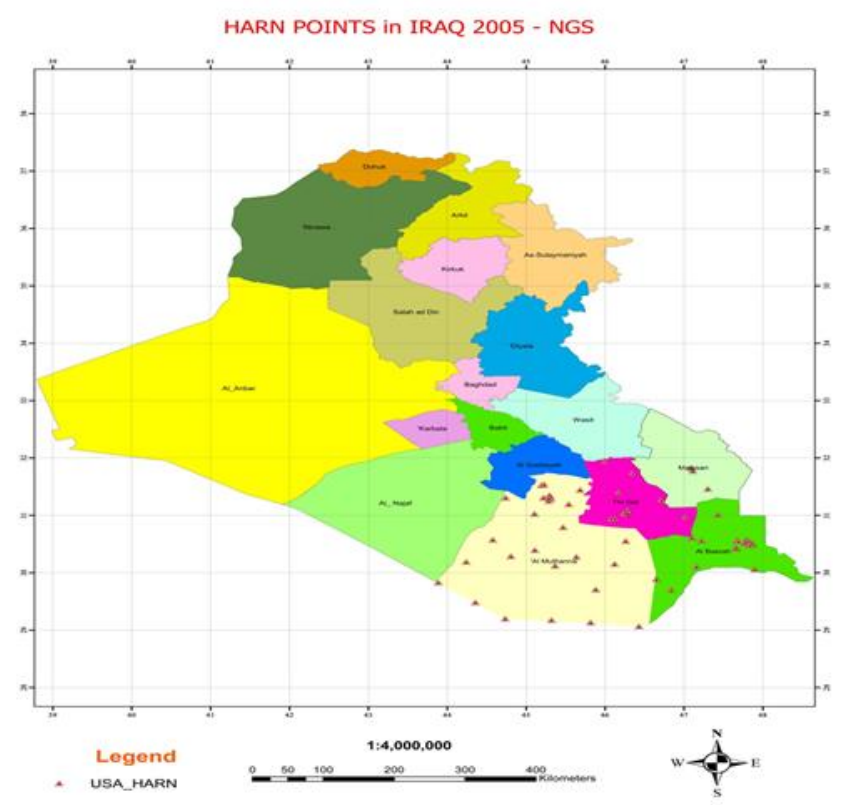

Fig.12 Map for high accuracy reference network (HARN) in Iraq 2005 

5.5 Continuously operating reference stations
of Iraqi general authority for surveying (CORS)



Fig.13.Map for (CORS) network in Iraq - IGRS

\subsection{Continuously operating reference stations of Iraqi general authority for surveying (CORS)}

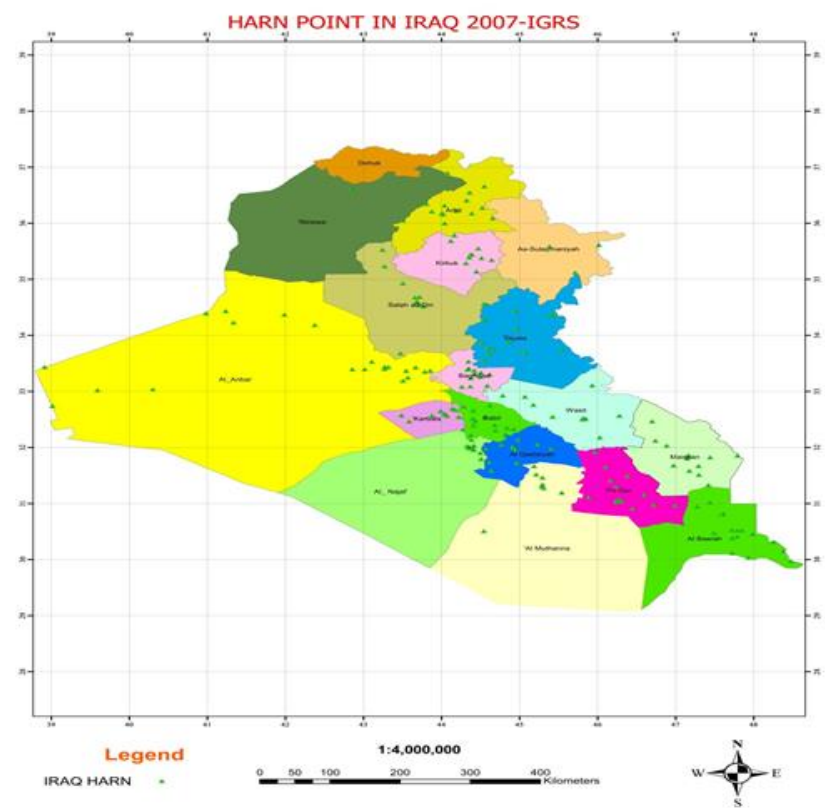

Fig.14. Map for high accuracy reference network (HARN) in Iraq 2007 to 2016



Fig.15. map for high accuracy reference network (HARN) in Iraq 2005 to 2016



Fig.16.Geodatabase for high accuracy reference network (HARN) in Iraq 2005 to 2016 
Table.6 Geodatabase for high accuracy reference network (HARN)

\begin{tabular}{|c|c|c|c|c|c|}
\hline point & Code & Location & East. & North. & ELEV. \\
\hline 01 & DQ01 & Thi Qar & 621452.078 & 3438594.909 & 5.299 \\
\hline 02 & DQ02 & Thi Qar & 618568.200 & 3432954.322 & 6.508 \\
\hline 03 & DQ03 & Thi Qar & 618053.464 & 3435422.901 & 4.180 \\
\hline 04 & DQ04 & Thi Qar & 611159.108 & 3475960.042 & 1.296 \\
\hline 05 & DQ05 & Thi Qar & 618011.963 & 3463616.072 & 1.725 \\
\hline 06 & DQ06 & Thi Qar & 604723.820 & 3503133.510 & 6.023 \\
\hline 07 & DQ07 & Thi Qar & 690793.343 & 3427588.589 & 9.367 \\
\hline 08 & DQ08 & Thi Qar & 664627.161 & 3427978.998 & 9.404 \\
\hline 09 & DQ09 & Thi Qar & 652368.232 & 3448873.044 & 9.091 \\
\hline 10 & DQ10 & Thi Qar & 591378.678 & 3531492.574 & 4.127 \\
\hline 11 & DQ11 & Thi Qar & 638578.686 & 3420464.993 & 6.535 \\
\hline 12 & DQ12 & Thi Qar & 624745.393 & 3435122.974 & 6.025 \\
\hline 13 & DQ13 & Thi Qar & 631242.612 & 3485316.793 & 4.190 \\
\hline 14 & DQ14 & Thi Qar & 584681.384 & 3442576.912 & 5.438 \\
\hline 142 & BS12 & Al Basrah & 761711.744 & 3334676.016 & 10.404 \\
\hline 143 & BS13 & Al Basrah & 781884.881 & 3326610.608 & 9.007 \\
\hline 144 & BS14 & Al Basrah & 255952.921 & 3318774.347 & 0.140 \\
\hline 145 & BS15 & Al Basrah & 247020.348 & 3338235.728 & 3.385 \\
\hline 146 & BS16 & Al Basrah & 760550.287 & 3364410.957 & 7.986 \\
\hline 147 & BS01 & Al Basrah & 772378.358 & 3380094.345 & 11.280 \\
\hline
\end{tabular}

\section{Recommandations}

To continue the research work in the future, and to go strongly toward solving the technical and administrative problems that are related with geodetic control networks, especially in the field of preparing their required corrected updated spatial data bases, the following recommendations are to be taken in considerations:

1- Enhancing the courses of Geodetic Control Networks for both undergraduate and postgraduate programs within all departments of colleges that are related with geomatics subject).

2- Preparing and supporting the advanced and practical training courses for scientific researchers and geomatics engineers in the field of Geodetic Control Networks, throughout increasing the scientific coordination between the academic sector ( geomatics wised colleges ) and the applied sector ( specialized directorates in geodetic surveying).

3- Establishing the Iraqi higher council for geodetic and cartographic activities, it could be helpful in the improvement of the technical and financial managements for the geodetic control networks projects.

4- Establishing the Digital Iraqi Gate for Geodetic Control Networks, this gate is specialized web. site, it will manage, control the accessibility and downloading for all geodetic official documents ( datasheets, sketches, photos, technical reports ), this gate could be run by the Iraqi higher council mentioned in the recommendation number 3 above.

\section{References}

1. W. Hussein, National geodetic networks of Iraq Between the past and the present (2011).

2. K. AlKadimi, Gravity control measurement to on basic station along Baghdad Basrah - Safwan road, Baghdad, Som (1977).

3. J. Gazdzicki, H. Kwiatkowshi , New Geodetic Control Network In Iraq Design, Surveys, And Data Processing , (1977).

4. K. AlKadimi, Gravity Basic Station Network of Iraq (1985). 